\title{
The importance of factor analysis in quantitative and qualitative $X$-ray diffraction phase analysis
}

\section{Význam faktorové analýzy pro kvantitativní a kvalitativní rentgenovou difrakční analýzu}

\author{
Camara A. H. \\ Czech Technical University in Prague, Faculty of Nuclear Sciences \\ and Physical Engineering, Czech Republic \\ E-mail: aly.hawa.camara@fjifi.cvut.cz
}

In the statistical treatment of measured data, factor analysis is often necessary. The methods involved can be used individually to emphasize the basic common factors in the group of variables; the factors produced can be then utilized as input data for other data analysis methods. The number of variables required to describe the system may be lowered, because the original variables may be correlated and, possibly, there is a smaller set of linearly independent variables. Thus, factor analysis is among the possible methods for the data analysis, when dealing with quantitative analytical measurements. Factor analysis of the measured data was used to lower the amount of variables in the analysis of steel; it was found that $94.5 \%$ of the overall variance in the data can be attributed to three factors. Three original variables were assigned to these factors, lowering the number of required variables.

\section{INTRODUCTION}

Factor analysis is a general term for a family of statistical techniques. It uses correlations between observed variables to estimate common factors. It makes use of second order statistics to extract signal so that signal to noise ratio can be increased. Also, factor analysis is concerned with the dimensional (number of variables) reduction of a set of observed data in terms of small number of latent factors [1-3].

Multivariate analyses such as principal component analysis (PCA) or factor analysis (FA), with the use of coefficients of linear correction, can serve such purpose. The FA is a more adequate multivariable technique when the goal is not only to reduce the number of variables but also to detect structures in the relationships between variables [4].
$V$ analýze dat jsou faktorové metody často nezbytné. Tyto techniky mohou být použity samostatně a snaži se zdůraznit základni společné faktory skupiny promènných, které mohou být také použity jako vstupní data pro dalši analýzy. Pak může docházet ke sniženi dimenze pole proměnných, nebot' pưvodní promènné mohou být korelované v menším počtu lineárnè nezávislých promènných. Pro kvantitativni analytické techniky je tudiž faktorová analýza jednou z použitelných metod. Pomocí faktorové analýzy namérených dat bylo zjištěno, že 94,5\% celkového rozptylu dat lze vysvětlit třemi faktory, kterým byly přiřazeny tři pưvodní proměnné. Došlo tedy k redukci dimenze pole proměnných.
X-ray diffraction analysis can be applied to nonamorphous substances - that is, crystalline or at least partially crystalline materials. The X-ray beams are significantly diffracted from the material only if the structure of the solid substance is more or less regular - this effect is the underlying physical principle of $\mathrm{X}$-ray diffraction analysis. It is known that the passage of X-ray beams through crystalline materials causes their diffraction. The directions of the diffracted beam depends on the structure of the compounds in the sample. $\mathrm{X}$-ray diffraction analysis uses this behaviour to identify crystalline phases present in the material.

Therefore, the X-ray diffraction can also analyze the corrosion products to take account of the ongoing changes in the process of corrosion. Usually, these changes affect the rate of corrosion and also reflect its advancement. These changes usually affect the rate of 
corrosion. The metal corrosion rate is influenced by the anion absorption which plays an important role in the catalyzer formation and in the activation energy of metal dissolution.

In this paper, factor analysis is discussed in relation to qualitative and quantitative phase diffraction analysis, the purpose of which is to provide unbiased quantitative information of determined phases without significant real structure. Therefore, the factor analysis for this case will be discussed theoretically and subsequently illustrated on a real sample collection.

The main application of factor analysis is to reduce data variables and classify them. PCA can be used for noise reduction in image by using the concept of dimensionality reduction and can be used in many applications, such as signal processing, data compressing, data visualization, image analysis and pattern recognition $[5,6]$.

Basically factor analysis extracts the set of factors from data set using correlation. Generally these factors are orthogonal and are ordered according to the proportion of the variance of the original data $[7,8]$.

The quantitative phase analysis using X-ray diffraction requires performing a qualitative phase analysis first. To avoid problems, it is advisable to determine the qualitative and quantitative phase composition simultaneously, which is called bilinear programming. The diffraction pattern $\vec{x}$ of a mixture containing $k$ different phases is composed of the contributions $c_{i} \vec{y}_{i}$ of its components:

$$
\vec{x}=\sum_{i=1}^{k} c_{i} \vec{y}_{i}
$$

where $\vec{y}$ stands for the diffraction pattern of $i$-th phase and $c_{i}$ represents the volume fraction (concentration) of $i$-th phase. Both sets of these variables must be calculated from the diffraction pattern of the mixture $\vec{x}$ analyzed.

Standard and statistically well-developed method of solving this task is factor analysis (FA). Factor analysis is a statistical method which was originally used only in psychology and over time expanded to other scientific areas such as economy, health, sociology, etc. With this method, we try to identify the factors, in this case vectors $\left\{\vec{y}_{1}, \vec{y}_{2}, \ldots, \vec{y}_{k}\right\}$. These factors can be found by analyzing the diffractograms of $p$ different fractions $\left\{\vec{x}_{1}, \vec{x}_{2}, \ldots, \vec{x}_{p}\right\}$, which must be separated from a given specimen. If these diffractograms $\vec{x}_{1}=\sum_{i=1}^{k} c_{l i} \vec{y}_{i}, l=1,2, \ldots p$ are independent, their Gram matrix

$$
\hat{G}=\left[\begin{array}{cccc}
\left(\vec{x}_{1}, \vec{x}_{1}^{T}\right) & \left(\vec{x}_{1}, \vec{x}_{2}^{T}\right) & \ldots & \left(\vec{x}_{1}, \vec{x}_{p}^{T}\right) \\
\left(\vec{x}_{2}, \vec{x}_{1}^{T}\right) & \left(\vec{x}_{2}, \vec{x}_{2}^{T}\right) & \ldots & \left(\vec{x}_{2}, \vec{x}_{1}^{T}\right) \\
\ldots & \ldots & \ldots & \ldots \\
\left(\vec{x}_{p}, \vec{x}_{1}^{T}\right) & \left(\vec{x}_{p}, \vec{x}_{2}^{T}\right) & \ldots & \left(\vec{x}_{p}, \vec{x}_{p}^{T}\right)
\end{array}\right]
$$

is regular and its eigenvectors $\left\{\vec{q}_{1}, \vec{q}_{2}, \ldots, \vec{q}_{n}\right\}$ create a complete orthogonal system. The Fourier series coeffi- cients of these fractions $v_{\text {li }}$ are proportional to the square root of the eigenvalue $\lambda_{\mathrm{i}}$ :

$$
\vec{x}_{l}=\sum_{i=1}^{n} v_{l i} \vec{q}_{i}^{T}=\sum_{i=1}^{n} u_{l i} \sqrt{\lambda_{i}} \vec{q}_{i}^{T} \quad ; l=1,2, \ldots, p
$$

where:

$$
\hat{G} \vec{q}_{i}=\lambda_{i} \vec{q}_{i} ; i=1,2, \ldots, n
$$

If the eigenvalues $\lambda_{1} \geq \lambda_{2} \geq \ldots \geq \lambda_{k} \geq \lambda_{k+1} \geq \lambda_{k} . \geq \lambda_{n}$ are arranged in descending order, the first $k$ eigenvalues correspond to the chemical variability of vectors, to $k$ factors. The remaining $n-k$ eigenvalues represent measurement errors or imperfect separation of vectors $\left\{\vec{y}_{1}, \vec{y}_{2}, \ldots, \vec{y}_{k}\right\}$. Due to their size, the eigenvalues $\lambda_{k+1}$, $\lambda_{k+2}, \ldots, \lambda_{n}$ are insignificant. Then:

$$
\sum_{i=1}^{k} c_{l i} \vec{y}_{i}=\vec{x}_{l} \approx \sum_{j=1}^{k} v_{l j} \vec{q}_{j}^{T} ; l=1,2, \ldots, p
$$

and therefore:

$$
\vec{y}_{i} \approx \sum_{j=1}^{k} T_{i j} \vec{q}_{j}^{T} ; l=1,2, \ldots, k
$$

To determine the concentration of components in the mixture, the matrix elements $T_{\mathrm{ij}}$ of a transformation matrix $\hat{T}$ should be calculated. To do this, we can use the fact that the intensity of the diffraction lines of the analyzed components and their concentrations can not be negative. In other words, it must be:

$$
\begin{aligned}
& \hat{Y}=\hat{T} \hat{W} \geq \hat{O} \\
& \hat{C}=\hat{X} \hat{W}^{T} \hat{T}^{T}\left(\hat{T} \hat{W} \hat{W}^{T} \hat{T}^{T}\right)^{-1} \geq \hat{O}
\end{aligned}
$$

where the upper index ${ }^{T}$ marks the transpose of a matrix,

$$
\begin{aligned}
& \hat{Y}=\left[\begin{array}{c}
\vec{y}_{1} \\
\vec{y}_{2} \\
\ldots \\
\vec{y}_{k}
\end{array}\right]=\left[\begin{array}{cccc}
y_{11} & y_{12} & \ldots & y_{1 n} \\
y_{21} & y_{22} & \ldots & y_{2 n} \\
\ldots & \ldots & \ldots & \ldots \\
y_{k 1} & y_{k 2} & \ldots & y_{k n}
\end{array}\right]=\hat{T}\left[\begin{array}{c}
\vec{q}_{1}^{T} \\
\vec{q}_{2}^{T} \\
\ldots \\
\vec{q}_{k}^{T}
\end{array}\right]=\hat{T} \hat{W} \\
& \hat{X}=\hat{C} \hat{Y}\left(\vec{x}_{1}=\sum c_{l i} \vec{y}_{i}, 1=1,2, \ldots, \mathrm{p}\right)
\end{aligned}
$$

and

The generic procedure for qualitative phase analysis of any complex mixture is also the most advanced technique of quantitative phase analysis. The most important source of uncertainty in the results of quantitative phase analysis is the real structure of the material (the size, shape and orientation of the crystals as well as their various internal defects), which affects an intensity of diffraction lines and is in general different for each sample. If the analyzed mixture can be separated into several factors using above-mentioned relations and the factors are not modified with the real structure, we can use the factor analysis of these diffractogram fractions to calculate intensities of diffraction lines of the individual components so that the influence of the real structure is taken into account and the uncertainty of the quantitative 
determination is reduced. The appli-cability of one statistical method for evaluation of both qualitative and quantitative phase analysis reflects the fact that both are just two different and essentially inseparable aspects of the phase analysis. A conservative adherence to the Wagnerian scheme ,first determine the quality and then quantity" is a disaster for the phase analysis and the real cause of the current dismal state - uncertainty of quantitative phase composition can not be reduced below the threshold for the method, which is around $1-10 \%$ absolute; moreover, a reliable, trouble-free identification of the qualitative composition of mixtures containing more than five ingredients is still to be found [9-17]. Quantitative determination of phase composition belongs to the oldest and most utilized X-ray powder diffraction analytical techniques. The real structure effects are suppresed by convenient sample preparation techniques or by measurement, determining the various real structure parameters and correcting the experimental intensity data for them [14].

Therefore in general, only a small subset of factors is considered as relevant, and the remaining factors are considered as either irrelevant or nonexistent. The observed variables can be then written as the linear combinations of the factors plus error terms:

$$
\hat{X}=\hat{C} \hat{Y}\left(\vec{x}_{1}=\sum c_{l i} \vec{y}_{i}, 1=1,2, \ldots, \mathrm{p}\right)
$$

In matrix notation it can be written as:

$$
X=A S+E
$$

where $X$ is the $N \times 1$ matrix consisting of $N$ samples; $S$ is a $N \times N$ matrix of factors scores (latent variables); $A$ is a $M \times N$ matrix of factor loadings and $E$ is a matrix of error terms. The factor analysis can be modeled in terms of variance and covariances:

$$
\sum=A \Phi A^{\mathrm{T}}+\Psi
$$

where $\sum$ is $M \times M$ population covariance matrix of the observed variables; $\Phi$ is the $N \times N$ covariance matrix of the factors; and $\Psi$ is the $M \times M$ residual covariance matrix. The primary assumption is that factors are uncorrelated, which implies covariance matrix should be identity matrix, i.e., $\Phi=\mathrm{I}$, and the $M$ - dimensional $e$ is distributed according to $N(0, \Psi)$, where $\Psi$ is a diagonal matrix. The assumption of diagonality of $\Psi$ implies that the observed variables are conditionally independent (given by the factors). The mean value of the observed variables $x$ as well as the covariance $\sum$ of this distribution must be equal to zero.

Factor analysis finds optimal $A$ and $\Psi$ using Expectation Maximanization (EM) algorithm [18]. The EM procedure is a two step iterative procedure for maximizing the logarithm of the probability. A detailed explanation of EM algorithm for finding maximum probability in factor analysis is given in [19]. After applying FA on experimental data, we found that it splits data matrix $X$ into factor score matrix $S$ and factor loading matrix $A$ given by (11). For the reduction of the measured data using PCA, the data are represented by a rectangular $M \times N$ matrix $X_{i j}(i=1,2, \ldots, M, j=1,2, \ldots, N)$. Here $i$ denotes the distance index. $N$ principal components of the data matrix $X$ are given by:

$$
Y=A^{T} X
$$

where $X=\left(x_{1}, x_{2}, x_{3}, \ldots,\right)^{T}$ is the input vector with the mean value of zero; $Y=\left(y_{1}, y_{2}, y_{3}, \ldots,\right)^{T}$ is the output vector called the vector of principal components (PCs); $A$ is an $M \times N$ matrix that transforms $X$ into $Y$. The purpose of PCA is to derive a relatively small number of decorrelated linear combination (principal component) of set of random variables while retaining as much of the information from the original variables as possible. The basic idea in PCA is to find the rows of the $y_{1}{ }^{T}, y_{2}{ }^{T}$, $y_{3}{ }^{T}, \ldots, y_{n}{ }^{T}$. PCA assumes that $A$ is an orthonormal matrix $\left(A_{i}{ }^{T} A_{j}=\delta_{i j}\right)$ such that the covariance matrix $C_{x}$ of $X$ is given by:

$$
C_{x}=\frac{1}{N} \mathrm{XX}^{\mathrm{T}}
$$

The eigenvector and eigenvalue matrices of $C_{x}$ are $\Phi$ and $\Lambda$ respectively and can be computed by:

$$
C_{x} \Phi=\Phi \Lambda
$$

where $\Lambda=\operatorname{diag}\left(\lambda_{1}, \lambda_{2}, \lambda_{3}, \ldots, \lambda_{N}\right)$ and $\left(\lambda_{1}, \lambda_{2}, \lambda_{3}, \ldots, \lambda_{N}\right)$ are the eigenvalues. After arranging the eigenvalues in the decreasing order $\lambda_{1} \geq \lambda_{2} \geq \lambda_{3} \geq \ldots \geq \lambda_{N}$, the matrix of $\mathrm{N}$ first eigenvectors $A$ is given by:

$$
A=\left[\Phi_{1}, \Phi_{2}, \Phi_{3}, \ldots, \Phi_{N}\right]
$$

Principal component matrix $S$ is then obtained by:

$$
S=A^{T} X
$$

However, the factor analysis (FA) is a more adequate multivariable technique when the goal is not only to reduce the number of the variables but also to detect structures in the relationships between variables. Therefore, the objective of this study was to identify the important sources of steel metallurgical fractions and total metals using FA.

Since factor analysis stems from a correlation matrix, the used variables should first of all be measured at an interval level (at least). Secondly, the variables should be roughly normally-distributed; this enables to generalize the results of your analysis beyond the sample collected. Thirdly, the sample size should be taken into considerations, as correlations are not robust, and can hence seriously influence the reliability of the factor analysis.

In a more recent study it was reported that as communalities become lower, the importance of sample size increases [20] and the communalities can be seen as a continuation of factor loading. 
As such, the communality of a variable represents the proportion of the variance in that variable that can be accounted for by all ('common') extracted factors. Thus if the communality of a variable is high, the extracted factors account for a big proportion of the variable's variance. This means that this particular variable is reflected well via the extracted factors, and hence that the factor analysis is reliable. When the communalities are not very high though, the sample size has to compensate for this. In SPSS program, a convenient option is offered to check whether the sample is big enough: the KaiserMeyer-Olkin measure of sampling adequacy (KMO-test).

After factor extraction it might be difficult to interpret name the components of the factors on the basis of their factor loadings. The criterion of principal component analysis is that the first factor accounts for the maximum part of the variance; this will often ensure that most variables have high loadings on the most important factor, and small loadings on all other factors. Thus, interpretation of the factors can be very difficult. A solution for this difficulty is factor rotation. Factor rotation alters the pattern of the factor loadings, and hence can improve interpretation. Rotation can best be explained by imagining the factors as axes in a graph, on which the original variables lie. Also there are two types of rotation: orthogonal and oblique rotation. In orthogonal rotation there is no correlation between the extracted factors, while in oblique rotation there is.

It is not always easy to decide which type of rotation to take; the choice of rotation depends on whether there is a good theoretical reason to suppose that the factors should be related or independent, and also how the variables are clustered around the factors before rotation. A fairly straightforward way to decide which rotation to take is to carry out the analysis using both types of rotation; if the oblique rotation demonstrates a negligible correlation between the extracted factors then it is reasonable to use the orthogonally rotated solution.

There are several methods to carry out rotations. SPSS offers five: varimax, quartimax, equamax, direct oblimin and promax. The first three options are orthogonal rotations; the last two are oblique. Most often, varimax is used in orthogonal rotation and direct oblimin in oblique rotation. Orthogonal rotation results in a rotated component factor matrix that presents the 'post-rotation' loadings of the original variables on the extracted factors, and a transformation matrix that gives information about the angle of rotation. In oblique rotation the results are a pattern matrix, structure matrix, and a component correlation matrix. The component correlation matrix presents the correlation between the extracted factors components, and is thus important for choosing between orthogonal and oblique.

Owing to large amount of data measured, a statistical analysis and subsequent graphical presentation of the results is an integral part of this work.

\section{EXPERIMENTAL AND MEASUREMENT PROCEDURE}

Total amount of 300 samples of steel obtained from different companies concerned with production of steel (Vítkovice, Böhler, Poldi Kladno) were analysed in this study. All the samples had identical dimensions: $20 \mathrm{~mm}$ $\times 20 \mathrm{~mm}( \pm 2 \mathrm{~mm})$, thickness $4 \mathrm{~mm}( \pm 1 \mathrm{~mm})$.

X-ray diffraction analysis of the steel samples was carried out on the D8 Discover Bruker AXS diffractometer, equipped with cobalt X-ray tube (Co-K $\mathrm{K}_{\alpha}, \lambda=1.78897 \AA$ ) and large multi-wire proportional detector (GADDS system) with 8192 pixels on an area of $314 \mathrm{~cm}^{2}$. The measured intensity of diffracted beams in this two-dimensional detector was integrated along the diffraction curves and recalculated into plot of intensity versus diffraction angle $2 \theta$. Area below the observed diffraction peaks on this plot was calculated. For a standard $1 \mathrm{~kW}$ X-ray tube the exposition time was tens of seconds, which corresponds to high sensitivity of this set-up. The integral intensity of the ferrite reflections was measured using constant settings and during a period as short as possible in order to minimize the possibility of parameter changes during the measurements [23].

Factor analysis and other processing of the measured intensities was carried out using Statistica program (Statsoft). Unrestricted Factor Analysis, Release Version 8.1, April, 2012, Rovira i Virgili University, Tarragona, SPAIN. In this work, FA was performed by evaluation of principal components and computation of the eigenvectors. Afterwards, the rotation of the principal components was carried out by the Varimax normalized method [21]. Principal component analysis (PCA) has been used to discriminate compositional patterns.

\section{RESULTS AND DISCUSSION}

From 300 prepared samples, the measured diffractograms of 30 different steel samples were chosen for analysis and 23 diffractograms were used for the factor analysis. The intensity ratios of 4 examined diffraction lines $[I(200)] /[I(110)],[I(211)] /[I(110)],[I(220)] /[I(110)]$, of the $\alpha$-Fe phase (ferrite, space group $\operatorname{Im} 3 \mathrm{~m}$ ) were computed (Tab. 1). Substantial variability of these ratios, which should be constant for an ideal, e.g. powder material, illustrates the strong influence of the real structure.

Effect of real structure on the results of the quantitative X-ray diffraction phase analysis is ever-present, but often also underestimated. Moreover, the results of the analysis of phase composition using X-ray diffraction cannot usually be verified by other methods (sometimes, an alternative phase analysis techniques utilizes other physico-chemical properties to quantify the phases). The effect of real structure may be illustrated by synthetic, powder samples with known phase composition and 
unknown real structure (generally different from sample to sample). The results of such work, for example, show that neglecting the influence of the real structure may produce an error of more than $10 \%$ of the calculated weight fraction $[22,23]$.

This was the reason why a subsequent factor analysis was made, with help of which it is possible to find out the dependencies between the analyzed variables of the samples, thus reducing the number of variables and eventually to identify, which part of the measured data variance is explainable by particular factors. The measured intensity ratios of diffraction lines (variables 5-7) and for completeness also the data covering absolute intensities of these lines (variables 1-4) were subjected to the factor analysis. A so-called Q-technique [6, 7, 18, 23] was used in this work, which can be explained as correlation between rows of data matrix or as determination of the relationships between single measurements. Using this technique, we obtain the relationships between subjects and information about the quantity of factors, i.e. about number of significant groups of subjects of similar measured attributes. Furthermore a so-called screen-test was used, which results from graphic representation of all eigenvalues of the correlation matrix in descending order by their size. If the correlation matrix is formed by independent stochastic values, then its eigenvalues lie more or less on a descending line. Every factor's contribution to overall variance of variables equals to the corresponding eigenvalue. According to Fig. 1, (4.144/7) $=59.2 \%$ of overall data variance can be interpreted by the first factor, $80.1 \%$ by two factors and $94.5 \%$ by three factors. The fourth factor contributes to the explanation of the measured data $(4.5 \%)$ only minimally and the rest of factors can be neglected (total of $1 \%$ ).

Each of first five factors, that were extracted following the screen-test (Fig. 1), is described by one column and each variable is described by one row of the rotated factor matrix, see Fig. 2. The fifth factor was

Tab. 1. Diffraction lines intensities and their ratios for measured samples / Hodnoty intenzit difrakčních linii ziskaných z difraktogramů a jejich vypočtených pomérů

\begin{tabular}{|c|c|c|c|c|c|c|c|}
\hline \multirow{4}{*}{ Sample No. } & \multicolumn{4}{|c|}{ Diffraction lines` intensities } & \multirow{4}{*}{$\mathbf{I}_{200} / \mathbf{I}_{110}$} & \multirow{4}{*}{$\mathbf{I}_{211} / \mathbf{I}_{110}$} & \multirow{4}{*}{$\mathbf{I}_{220} / \mathbf{I}_{110}$} \\
\hline & $I_{110}$ & $\mathbf{I}_{200}$ & $\mathbf{I}_{211}$ & $\mathbf{I}_{220}$ & & & \\
\hline & \multicolumn{4}{|c|}{ Inter-planar distance [pm] } & & & \\
\hline & 203 & 143 & 117 & 101 & & & \\
\hline 1 & 120 & 8 & 14 & 3 & 0.067 & 0.117 & 0.025 \\
\hline 2 & 124 & 10 & 23 & 9 & 0.081 & 0.185 & 0.073 \\
\hline 3 & 50 & 4 & 4 & 3 & 0.080 & 0.080 & 0.060 \\
\hline 4 & 77 & 5 & 14 & 4 & 0.065 & 0.182 & 0.052 \\
\hline 5 & 190 & 15 & 28 & 9 & 0.079 & 0.147 & 0.047 \\
\hline 6 & 70 & 16 & 10 & 8 & 0.229 & 0.143 & 0.114 \\
\hline 7 & 142 & 16 & 33 & 13 & 0.113 & 0.232 & 0.092 \\
\hline 8 & 101 & 9 & 27 & 8 & 0.089 & 0.267 & 0.079 \\
\hline 9 & 76 & 6 & 13 & 6 & 0.079 & 0.171 & 0.079 \\
\hline 10 & 51 & 3 & 10 & 4 & 0.059 & 0.196 & 0.078 \\
\hline 11 & 60 & 4 & 13 & 3 & 0.067 & 0.217 & 0.050 \\
\hline 12 & 70 & 5 & 20 & 7 & 0.071 & 0.286 & 0.100 \\
\hline 13 & 44 & 4 & 12 & 3 & 0.091 & 0.273 & 0.068 \\
\hline 14 & 103 & 7 & 13 & 2 & 0.068 & 0.126 & 0.019 \\
\hline 15 & 147 & 9 & 24 & 10 & 0.061 & 0.163 & 0.068 \\
\hline 16 & 98 & 9 & 23 & 8 & 0.092 & 0.235 & 0.082 \\
\hline 17 & 63 & 6 & 12 & 7 & 0.095 & 0.190 & 0.111 \\
\hline 18 & 79 & 7 & 18 & 8 & 0.089 & 0.228 & 0.101 \\
\hline 19 & 183 & 23 & 46 & 16 & 0.126 & 0.251 & 0.087 \\
\hline 20 & 175 & 17 & 45 & 15 & 0.097 & 0.257 & 0.086 \\
\hline 21 & 114 & 12 & 26 & 11 & 0.105 & 0.228 & 0.096 \\
\hline 22 & 140 & 18 & 39 & 13 & 0.129 & 0.279 & 0.093 \\
\hline 23 & 98 & 5 & 12 & 4 & 0.051 & 0.122 & 0.041 \\
\hline
\end{tabular}




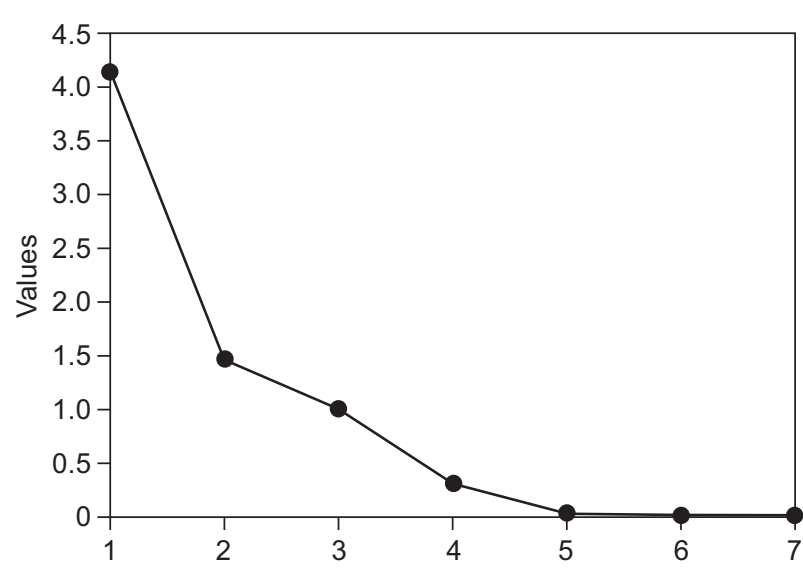

Fig. 1. Eigenvalues of the correlation matrix by size Obr. 1. Vlastní čísla korelační matice podle velikosti

\begin{tabular}{|c|c|c|c|c|c|}
\hline & 0.99 & 0.12 & 0.04 & 0.02 & 0.12 \\
\hline & 0.84 & 0.09 & 0.09 & 0.51 & 0.06 \\
\hline & 0.89 & 0.10 & 0.42 & 0.06 & 0.10 \\
\hline & 0.83 & 0.44 & 0.25 & 0.20 & 0.08 \\
\hline & 0.14 & 0.29 & 0.02 & 0.95 & 0.00 \\
\hline & 0.18 & 0.26 & 0.95 & 0.03 & 0.01 \\
\hline & 0.05 & 0.87 & 0.33 & 0.36 & 0.01 \\
\hline & 1 & 2 & $\begin{array}{c}3 \\
\text { Factors }\end{array}$ & 4 & 5 \\
\hline
\end{tabular}

Fig. 2. Factor diagram - factor saturation values Obr. 2. Faktorové schéma-hodnoty faktorové saturace

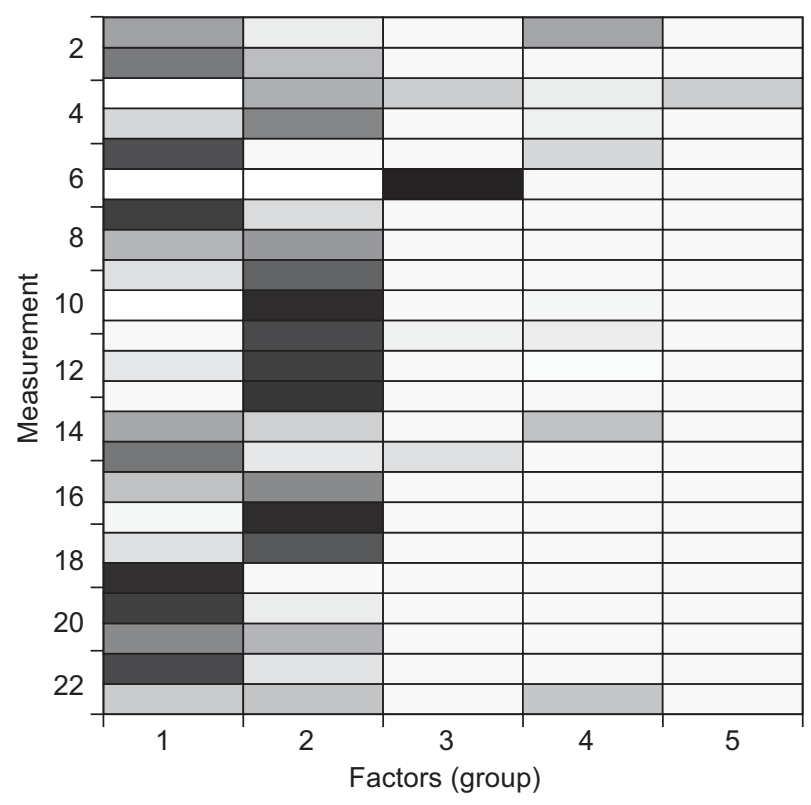

Fig. 3. Q-factor matrix (absolute values)

Obr. 3. Q-Faktorová matice (absolutní hodnoty) extracted only as a measure of noise. The bigger the absolute value of factor saturation is (values in Fig. 2), the tighter connection between corresponding value and factor. Based on Fig. 1 and 2, we can deduce that measured intensities and their ratios can be substituted by three orthogonal factors $\{1,2,3\}$, which in sequence correspond to the intensity of line (110), $[I(211)] /[I(110)]$ ratio and $[I(220)] /[I(110)]$ ratio. Another way of reducing the data dimension by factor analysis is to compute entirely new parameters called factor scores. This approach is more proper due to an aspect of preservation of information. However, practice proved that even trivial selection of original parameters represents the extracted factors well.

Fig. 3 shows particular factor's occurrence in measured reference samples using greyscale - darker rectangle means more significant influence of the concerned factor (column) in the sample (row). From Fig. 3 can be seen that the factors 1,2 and 3 significantly occur in all studied samples and the others represent a noise.

Based on the factor analysis of the data measured on the steel samples, we can say that intensities of ferrite diffraction lines can be described by three factors which can be thereafter used for quantitative analysis of steel samples.

This method converts a generally difficult problem of estimation of phase composition of compound onto a considerably simpler task of identification of elementary substance's diffractograms (particular components) obtained by factor analysis. Presented technique is also well applied as a versatile method of correcting the influence of real structure. Separation as a result can be also applied for different wavelengths. Due to anomalous dispersion and micro-absorption, the intensity of radiation diffracted by different phases of the examined sample varies disproportionally. By applying the factor analysis on diffractograms of given compound obtained using different radiations it is possible to reconstruct the diffractograms of its components and to determine the quantitative composition of the compound as well.

Contribution of this work lies mainly in the reduction of the data using factor analysis, when the large number of variables is transformed into new group of variables with a much smaller dimension. The character of the original variables is maintained, while multidimensional data analysis is greatly simplified. The methods presented can be easily utilized in any qualitative and quantitative diffraction analysis to separate the contribution of the real structure to the measured diffraction pattern.

\section{CONCLUSIONS}

In this paper, an example of factor analysis application is presented it the field of material sciences study - X-ray diffraction on the steel samples. Princi- 
pal component analysis applied to the data obtained was performed using oblique rotation, even though multicollinearity was found to be present in the experimental data. The multicollinearity was, however, adequately accounted for in the factor analysis.

The measured data were subjected to factor analysis, with which it was found that $94.5 \%$ of the measured data can be explained by three factors; they were rotated by means of the factor matrix and assigned to each variable. The fourth factor contributes only minimally and the remaining factors are the remaining noise. Thus, linearly independent information that characterizes the measured data almost entirely are the intensity of the strongest line of ferrite (110) and the ratios of (211) or (220) lines to the most intense line (110).

\section{REFERENCES}

1. Chen C. H., Zhenhai W. ICA and factor analysis application in seismic profilig, IEEE International Conference on Geoscience and Remote Sensing Symposium August 2006, $1560-1563$.

2. Wu N., Zhang J. Factor analysis based Antaly detection, Informatik Assurance Workshop, IEEE Systems, Man and Cybernetics Society June 2003, 108-115.

3. Hong S. Warped image factor analysis, $1^{\text {st }}$ IEEE International Workshop on Computational Advances in Multisensor Adaptive Processing December 2005, 121-124.

4. Maiz I., Arambarri I., Garcia R., Millán E. Evalution of heavy metal avalability in polluted soils by two sequential extraction procedures using factor analysis, Enviromental pollution 2000, 110, 3-9.

5. Reisenauer R. Metody matematické statistiky, Polytechnická knižnice 1970, 46. svazek II. řady prríručky.

6. Chlada M. Zpracování signálů akustické emise pomocí umělých neuronových sítí, Disertační práce 2008, ČVUT FJFI Katedra matematiky.

7. Verma P. K., Gaikwad A. N., Singh D., Nigam M. J. Analysis of cluster reduction techniques for through wall paging in USB range, Progress In Electromagnetics Reaserch $B$ 2009, 17, 29-48.

8. Chavent M., Kuentz V., Saracco J. Analyse en Facteurs: présentation et comparaison des logiciels SAS, SPAD et SPSS, Revue MODULAD 2007, 37, 1-30.

9. Fiala J. Kvalitativní a kvantitativní fázová analýza, 1994, ISBN 80-85488-01-9.

10. Kochanovská A. Principy fázové kvantitativní analýzy, Materiálový sbornik SVÚMT 1965.

11. Davis B. L. Reference Intensity Metod of Quantitative X-ray Diffraction Analysis, South Dakota School of Mines and Technology 1988.

12. Bish D.L., Post J.E. (eds) The Modern Powder Diffraction, The Mineralogical Society of America 1989.

13. Fiala J. Self - calibrating Techniques in Powder Diffraction Phase Analysis, Godišnjak Jugoslavcenkog Centra za Kristalografiju 25 1990, 1-8.

14. Fiala J. Quo Vadis Quantitative powder diffraction phase analysis, Materials Science Forum 1991, 79-82, 27-34.

15. Zevin L. S., Kimmel G. Quantitative X-ray Diffractometry, Springer-Verlag 1955.

16. Fiala J. Materials Science Forum 1991, 79-82, 27-34.

17. Meloun M., Militký J. Statistická analýza experimentálních dat, ISBN 80-200-1254-0 2004.

18. Saul L. K., Rahim M. G. Maximum likelihood and minimum clasification error factor analysis for automatic speech recognition, IEEE Trans. Spech Audio Process 2000, 8 (2), 115-125.

19. Rubin D., Thayer, D. EM algorithms for factor analysis, Psychometrika 1982, 47 (1), 69-76.

20. Field A. Discovering Statistics using SPSS for Windows, New Delhi-Sage publications 2001.

21. Application of Factor Analysis in Geochemical Fiction Haevy Metals in the Surface Sediments of the Offshore and Intertidal Areas of Peninsular Malaysia, Sals Malaysiana 2012, 41 (4), 389-394.

22. Fiala J. Quo Vadis Quantitative powder diffraction phase analysis, Materials Science Forum 1991, 79-82, 27-34.

23. Camara A. H. Aplikace faktorové analýzy na reálnou strukturu kovových materiálů, Hutnické listy 2013, 66 (3), 60-64. 